\title{
Reducing Cosmopolites sordidus populations and damage using traps baited with pheromone and plantain corm
}

\section{Reducción de poblaciones y daños de Cosmopolites sordidus mediante trampas cebadas con feromona y cormo de plátano}

\author{
Rodolfo Osorio-Osorio ${ }^{1 *}$, José Isabel López-Naranjo ${ }^{1}$, Efraín de la Cruz-Lázaro ${ }^{1}$, Cesar Márquez-Quiroz ${ }^{1}$, \\ Rosa Ma. Salinas-Hernández ${ }^{1}$, Juan Cibrián-Tovar ${ }^{2}$ \\ ${ }^{1}$ Universidad Juárez Autónoma de Tabasco, División Académica de Ciencias Agropecuarias, Km 25 carretera \\ Villahermosa-Teapa. CP. 86298. Centro, Tabasco, México \\ ${ }^{2}$ Colegio de Postgraduados, Instituto de Fitosanidad, Km 35.5 carretera México-Texcoco. CP. 56230 Montecillo, Estado de \\ México, México \\ *Corresponding author: rodolfo.osorioo@gmail.com
}

scientific article received: august 1,2016 , accepted: September 4, 2016

\begin{abstract}
The banana weevil Cosmopolites sordidus is an important pest in plantain and banana crops throughout the world. The objective was to evaluate a mass trapping system based on traps baited with synthetic pheromone (sordidin) + plantain corm tissue to reduce $C$. sordidus populations and damage in the Centro-Chontalpa region of Tabasco state, Mexico. The experiment was carried out on plots of about two to three hectares of Horn plantain Musa AAB infested by $C$. sordidus. Treatments were four traps ha ${ }^{-1}$, eight traps ha ${ }^{-1}$ and a control (without traps). Population density and damage in corms of small plants (suckers) were reduced after six months of mass trapping, while damage in corms of mature plants (freshly harvested) only decreased significantly after 13 months of trapping. By doubling the number of traps, the reduction in the $C$. sordidus population and damage was not significant. The use of four traps ha ${ }^{-1}$ baited with synthetic pheromone + plantain corm is a technically feasible strategy that provides at least partial control of this pest under local Horn plantain production conditions.
\end{abstract}

Keywords: Banana weevil, aggregation pheromone, sordidin

RESUMEN. El picudo del plátano Cosmopolites sordidus es una plaga importante en los cultivos de plátano y banano en el mundo. El objetivo fue evaluar un sistema de captura masiva basado en trampas cebadas con feromona sintética (sordidin) + tejidos de cormo de plátano para reducir las poblaciones y daños de esta plaga en la región Centro-Chontalpa del estado de Tabasco, México. El experimento se llevó acabo en parcelas de dos a tres hectáreas de plátano Macho Musa AAB Plantain infestadas de $C$. sordidus. Los tratamientos fueron cuatro trampas ha ${ }^{-1}$, ocho trampas ha ${ }^{-1}$ y un testigo (sin trampas). La densidad poblacional y el daño en cormos de plantas pequeñas (retoños) se redujeron después de seis meses de captura masiva, mientras que el daño en cormos de plantas maduras (recién cosechadas) solo disminuyó de forma significativa a los 13 meses de captura. Al duplicar el número de trampas, la reducción poblacional y los daños de $C$. sordidus no fue significativa. El uso de cuatro trampas ha ${ }^{-1}$ cebadas con feromona sintética + cormo de plátano es una estrategia técnicamente factible que proporciona al menos un control parcial de esta plaga, bajo las condiciones locales de producción de plátano macho.

Palabras clave: Picudo del banano, feromona de agregación, sordidin

\section{INTRODUCTION}

The banana weevil, Cosmopolites sordidus (Germar) (Coleoptera: Curculionidae), is the most important pest insect of plantains and bananas (Musa spp.) in the world (Gold et al. 2001). During feeding, the larvae of this species cause tunnels or galleries in the corm, pseudostem and roots 
of the plant, affecting its anchorage, vigor and vascular conduction system (Paull and Duarte 2011). Damaged tissues are often invaded by decay-causing fungi and bacteria (Muniappan et al. 2012). Severe damage can result in death or loss of entire plants, or retard growth and development, affecting the size and weight of harvested fruit (Rukazambuga et al. 1998, Gold et al. 2005). In Tabasco, Mexico the Horn plantain cultivar Musa AAB Plantain is highly susceptible to attack by this pest. The most severe damage occurs in the Centro-Chontalpa region, where crop areas with $60 \%$ infested plants and up to $20 \%$ damaged tissue in the corm of plants at maturity or productive stage have been found. In these plots it is common to observe the breakage or overturning of whole plants or mats due to $C$. sordidus damage (Osorio-Osorio et al. 2006). Although the application of residual insecticides is an alternative to combat this pest in the region (Ramírez and Rodríguez 2003), it is necessary to search for control methods with less environmental impact.

Pheromones are chemical signals used for communication between individuals of a species (Wyatt 2003), and are considered the safest chemicals available to control pest insects (Minks and Kirsc 1998). The practical application of pheromones includes three main strategies: monitoring (sampling and detection), mass trapping (attract and kill) and mating disruption (inhibition of chemical communication) (Wyatt 2003). Mass trapping aims at the removal of a large proportion of the adult population by means of a sufficient number of traps (Tinzaara et al. 2002). This method assumes that reducing the number of adults in the population will result in a decreased number of individuals in subsequent generations (El-Sayed et al. 2006). The aggregation pheromone of $C$. sordidus was identified as (IS*,3R*, $\left.\mathrm{SR}^{*}, 7 \mathrm{~S}^{*}\right)$ 2,8-dioxa 1-ethyl 3,5,7-trimethyl bicylo [3,2,1] octane 1d, a compound commonly known as sordidin (Beauhaire et al. 1995, Ndiege et al. 1996, Jayaraman et al. 1997). The use of this compound in a mass trapping system for controlling $C$. sordidus has given contrasting results. Between 1997 and 1998, in Dwarf Cavendish banana (Musa AAA) plots in Costa Rica, mass trapping of adults using five sordidin-baited traps ha ${ }^{-1}$, after 12 consecutive months, reduced C. sordidus populations and damage and increased the weight of harvested banana bunches by $23 \%$ (Alpizar et al. 2012). By contrast, between 1999 and 2002, in banana cultivar Mbwazirume (Musa AAA-EA) plantations, the use of four or eight traps ha $^{-1}$ baited with the same pheromone for 21 consecutive months did not reduce $C$. sordidus populations or damage (Tinzaara et al. 2005). In fact, the success of a mass insect trapping system based on traps baited with aggregation pheromone may be influenced by several factors, including trap density (Schlyter 1992), trap type (Reddy et al. 2009), the environment (Duyck et al. 2012), and the use of kairomones in the trap (Piñero and Ruiz-Montiel 2012), among other factors.

In several species of the family Curculionidae, it has been found that the volatile compounds emanating from host plants, known as kairomones, synergize the physiological response and behavior of this taxonomic group of insects to their respective aggregation pheromones (Cibrián-Tovar et al. 2006, Piñero and Ruiz-Montiel 2012, Muñiz-Merino et al. 2014). The use of corm or pseudostem of bananas or plantains (Musa spp.) as an attractant for C. sordidus has been studied (Cerda et al. 1996, Cerda et al. 1998, Mazanza et al. 2009). It is known that fresh or fermented pseudostem tissue increase captures in sordidin-baited traps, but its effect is not large enough to optimize the $C$. sordidus trapping system (Tinzaara et al. 2007). By contrast, it has been observed that the addition of corm tissue in traps baited with this same pheromone increases more than tenfold the capture of C. sordidus (Cerda et al. 1998). In Tabasco, Mexico, corm, pseudostem, leaf and fruit tissues of Horn plantain Musa AAB were evaluated as coattractants in traps baited with sordidin, confirming that the addition of corm tissue significantly increases the capture of $C$. sordidus (Osorio-Osorio et al. 2006). Several authors believe that fresh or volatile plantain tissue could be used to enhance the attraction of the synthetic pheromone of $C$. sordidus (Ndiege 1996, Cerda et al. 1998, Masanza 
et al. 2009), while others regard it as a matter of priority to investigate (Gold et al. 2001, Tinzaara et al. 2002). The availability of fresh plant material in the field can be one of the major constraints; however, in plots with high damage rates, where the urgency to implement control measures lies, there are many broken or overturned plants from which corms can be obtained without destroying healthy plants (Osorio-Osorio et al. 2006). Against this background, the aim of this study was to evaluate a mass trapping system based on the use of traps baited with synthetic pheromone (sordidin) + plantain corm in order to reduce $C$. sordidus populations and damage in Horn plantain Musa AAB plantations in Tabasco, Mexico, which will help determine the practicality of using this mass trapping system as an alternative to chemical pest control in the region.

\section{MATERIALS AND METHODS}

\section{Experimental site}

The experiment was conducted in Horn plantain (Musa group $A A B$, subgroup Plantain) plots worked by small-scale producers of the localities of Plátano and Cacao $1^{a}$ sección (17 $56^{\prime} \mathrm{NL}$ and $93^{\circ}$ $09^{\prime} \mathrm{WL}$ ), Cucuyulapa $1^{a}$ sección $\left(17^{\circ} 58^{\prime} \mathrm{NL}\right.$ and $93^{\circ} 14^{\prime} \mathrm{WL}$ ) and Corregidora $4^{\mathrm{a}}$ sección ( $17^{\circ} 57^{\prime} \mathrm{NL}$ and $93^{\circ} 13^{\prime} \mathrm{WL}$ ) in the Centro-Chontalpa region of Tabasco state, Mexico. The region has a hot-humid climate (Am), with annual rainfall of 1600-2500 mm (Larios-Romero and Hernández 1987). In general, the region has three identifiable climatic periods in the year; a dry period from March to May, with high temperatures and little rain; a storm period from June to September, with rains in the form of torrential downpours of short duration; and a cold front period from October to February, with prolonged low-intensity rains (drizzles) associated with cloudy days (Larios-Romero and Hernández 1987).

\section{Characteristics of the plantations}

In each locality three plantain plots infested with C. sordidus, located approximately $500 \mathrm{~m}$ apart, were selected. The plantations were between seven and 10 years old, planted in a real $3 \times 3$ $\mathrm{m}$ framework. All plots had a drainage system to evacuate excess rainwater, periodic application of fungicides to control black sigatoka caused by Mycosphaerella fijiensis and manual weed control. There was little or no destruction of crop residues; mature plants after harvest remain in the mat or stump to decay naturally, since according to the region's producers they serve to support or sustain suckers or shoots.

\section{Trap type}

Ramp-type traps (Figure 1), which were manufactured with a white, 4-L plastic bucket, 20 $\mathrm{cm}$ in diameter by $20 \mathrm{~cm}$ high, were used. Three equidistant rectangles, $16 \mathrm{~cm}$ wide by $10 \mathrm{~cm}$, were marked in the lateral area of each container, on which cuts were made on the lateral and top lines of each polygon. The tabs resulting from the cuts were folded down to form the ramps of the trap, while at the top of the bucket a removable plastic cage of $8 \mathrm{~cm}$ in diameter by $10 \mathrm{~cm}$ high was assembled, as a container for the fresh corm tissue and synthetic pheromone bait (Figure 1).

\section{Mass trapping scheme}

Three treatments, namely four traps ha ${ }^{-1}$ (low density), eight traps ha ${ }^{-1}$ (high density) and a control (without traps), were evaluated. Each treatment was evaluated in three plots of approximately two to three hectares of Horn plantain located in three different locations, giving a completely randomized block design. The number of traps required per plot was calculated by multiplying the density of traps by the size of the plot. The trapping scheme was as follows: in the treatment with four traps $\mathrm{ha}^{-1}$, the experiment began by placing four traps at a distance of $10 \mathrm{~m}$ from the edge of the plantation, spaced $20 \mathrm{~m}$ apart. In the second month, this series of traps was moved $20 \mathrm{~m}$ to the interior of the plantation, and so on until covering a hectare of crop in five months. In the sixth month, the series of traps was returned to the initial trapline to continue with another displacement through the plantation, and so on until the end of the experiment. In the experiment with eight traps ha ${ }^{-1}$, two series of 

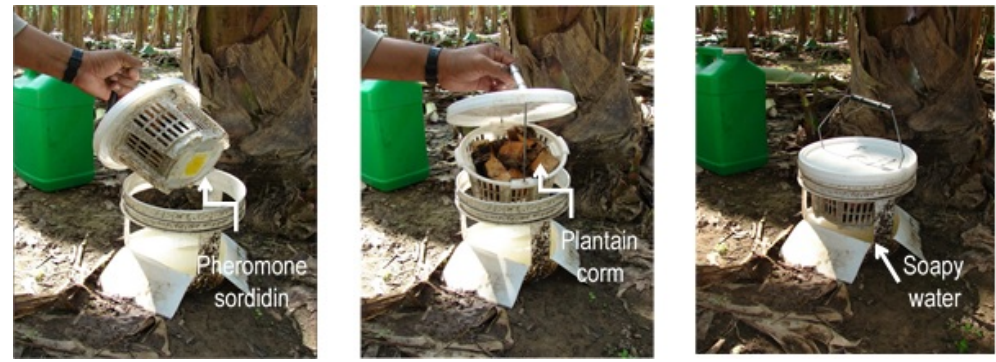

Figure 1. Design of trap baited with the pheromone sordidin $\left(\right.$ Cosmolure+ $\left.{ }^{\circledR}\right)$ and plantain corms for capturing Cosmopolites sordidus adults in Tabasco, México.

adjacent traps, with the same spacing and starting position indicated above, were placed. Each month, both series of traps were systematically moved into the plantation to cover one hectare, then returned to the starting position until concluding the mass trapping period. All traps were baited with one unit of (Cosmolure+ ${ }^{\circledR}$ ) (Chemtica International, San José, Costa Rica) with $90 \mathrm{mg}$ of pheromone at a release rate of $3 \mathrm{mg} \mathrm{day}^{-1}$ (Tinzaara et al. 2005), which was replaced each month. Also, $800 \mathrm{~g}$ of fresh Horn plantain corm tissue as kairomone and a soapy water solution containing $500 \mathrm{ml}$ of water +2 $\mathrm{g}$ of detergent were placed in each trap, as a means of trapping and annihilating the weevils attracted to the trap. Each trap was placed on one side of the plantain mats under the canopy shade of the plants (Reddy et al. 2009). Every week the traps were reviewed to record the number of weevils captured, replace the rotted or dried-out corm tissue and change the soapy water solution. The trapping period was 13 months, starting in march 2012 and ending in march 2013. Of the total number of weevils captured per month, a $25 \%$ sample was taken. The specimens were dissected under a stereoscope microscope to determine their sex and the number of resident eggs in the reproductive system of the females.

\section{Population estimate}

The adult $C$. sordidus population density was estimated before the start of the mass trapping (January 2012) and eight months (September 2012) and 15 months (April 2013) after. The trapping, marking and recapturing method of Petersen (Krebs 1999) was used. To capture adults, pieces of plantain pseudostem of about $30 \mathrm{~cm}$ in length were used as an attractant (Osorio-Osorio et al. 1996); they were cut lengthwise and placed beside plantain mats at an approximate distance of $6 \mathrm{~m}$ apart throughout the plot under study. Three days later, the pseudostems were reviewed for the collection of live weevils, which were marked and released at the same trapping site (Gold and Bagabe 1997). The marking was made on the right elytra of each weevil with indelible oil-based ink (Staedler ${ }^{\circledR}$ ), which was previously assessed as safe for insects and resistant to environmental degradation. In total, between $\mathbf{4 0 0}$ and 480 weevils per plantation hectare were marked and released. Two weeks later, a period in which considerable mixing of released adults with the rest of the population has been shown (Gold and Bagabe 1997), fresh pseudostems were once again placed as an attractant in the study plots for a second trapping. Three days later, they were reviewed to record the total number of weevils captured, marked and unmarked. The adult population estimate was calculated using the equation $N=\frac{C M}{R}$, where = is the estimated population size in the plot, $M=$ number of marked weevils released in the plot, $C$ $=$ total number of weevils captured (marked and unmarked) in the second trapping period, and $R$ $=$ number of recaptured weevils (marked). In all cases, the adult population estimate was extrapolated to one hectare. Given the prolonged longevity, low fecundity and limited dispersal of adult $C$. sordidus (Gold et al. 2001), it is considered that the 
assumptions of the Petersen method (Krebs 1999) were met.

\section{Damage assessment}

Pest damage was evaluated in the corm of freshly harvested mature plants and in the corm of small plants known as suckers or shoots. Evaluations were made prior to the establishment of the experiment, and six and 13 months after having implemented mass trapping (March and September 2012 and April 2013, respectively). The percentage of damage in the corms of mature plants was quantified using the cross-section method (Gold et al. 2005), as follows: 1) two cross-section cuts were made per corm, one at the corm/pseudostem junction (collar of the plant) and the other $5 \mathrm{~cm}$ below the collar, over the area of the corm; 2) in each cut, the central cylinder and outer cortex areas were identified; 3 ) in each area the percentage of visible damage (tunnels and galleries) caused by $C$. sordidus larvae over the corm area was obtained; 4) the four data were averaged to estimate the percentage of total damage per corm, since the combined damage of the central cylinder and the corm cortex has shown a better relationship with harvested fruit losses (Gold et al. 2005). In each plot a sample size of 30 plants, selected at random in the central plantation area (50\% of the trapping area), was considered. As for assessing the damage in small plants (suckers 15 to $25 \mathrm{~cm}$ in height), 30 plants were randomly sampled on each assessment date and in each experimental plot. It is known that the tunnels or galleries caused by the weevil in the corm of mother plants can spread to the corm of the suckers of the same mat (Gold et al. 2001). Therefore, cuts were made in the corm of each plant to locate tunnels or galleries of $C$. sordidus larvae. Suckers that had at least one tunnel or gallery were considered as damaged.

\section{Statistical analysis}

The number of weevils captured per trap per month with four traps ha ${ }^{-1}$ and eight traps ha ${ }^{-1}$ were compared with the Student's t-test. Prior to analysis of variance, the adult population density data were transformed to logarithms $y_{i j}^{\prime}=\log _{10} y_{i j}$ and the percentages of damage in mature plants and suckers to arc sine values $y_{i j}^{\prime}=\operatorname{arsin} \sqrt{y_{i j} / 100}$. Multiple comparisons of means were performed using the Tukey method (Zar 2010). In addition, the Pearson product-moment correlation coefficient was applied between the monthly capture rates and the rainfall $(\mathrm{mm})$ of the study area. In all cases $\mathrm{p}$ $<0.05$ was considered as significant. Analyses were performed with the TTEST, GLM and CORR procedures of the SAS statistical package (SAS 2009).

\section{RESULTS}

Prior to the establishment of the experiment, the adult $C$. sordidus population densities were 47 $838 \pm 6175$ weevils ha ${ }^{-1}$ in the plots treated with four traps ha ${ }^{-1}, 42062 \pm 5421$ weevils ha ${ }^{-1}$ in the plots with eight traps ha ${ }^{-1}$ and $44062 \pm 5$ 689 weevils ha ${ }^{-1}$ in the control plots (Figure 2). These populations were not statistically different $(p$ $=0.33$ ). In subsequent evaluations, after six and 13 months of trapping, populations were significantly reduced in plots treated with both trap densities ( $p$ $<0.05$ ) (Figure 2). Although populations fell more in the plots treated with eight traps $\mathrm{ha}^{-1}$, the differences were not statistically significant. After 13 months of mass trapping, the average population of this insect decreased to $21819 \pm 4436$ and 18068 \pm 3419 weevils, with four and eight traps ha ${ }^{-1}$, respectively. By contrast, in plots without traps the average population increased to $48883 \pm 4707$ weevils ha ${ }^{-1}$.

For the capture rates per trap per month, with the use of four traps ha ${ }^{-1}$, on average 46.7 weevils per trap were recorded, with a range of 20.9 to 84.0 , whereas in the density of eight traps ha ${ }^{-1}, 37.6$ weevils per trap were captured with a range of 14.8 to 68.1 (Figure 3). Overall, capture rates were higher in the first six months of trapping, 44.6 to 84.0 with four traps ha ${ }^{-1}$ and 43.6 to 68.1 with eight traps $\mathrm{ha}^{-1}$, which is attributable to the higher $C$. sordidus population density at the beginning of the experiment. From the sixth month until the end of the research, captures decreased gradually (Figure 3 ). 


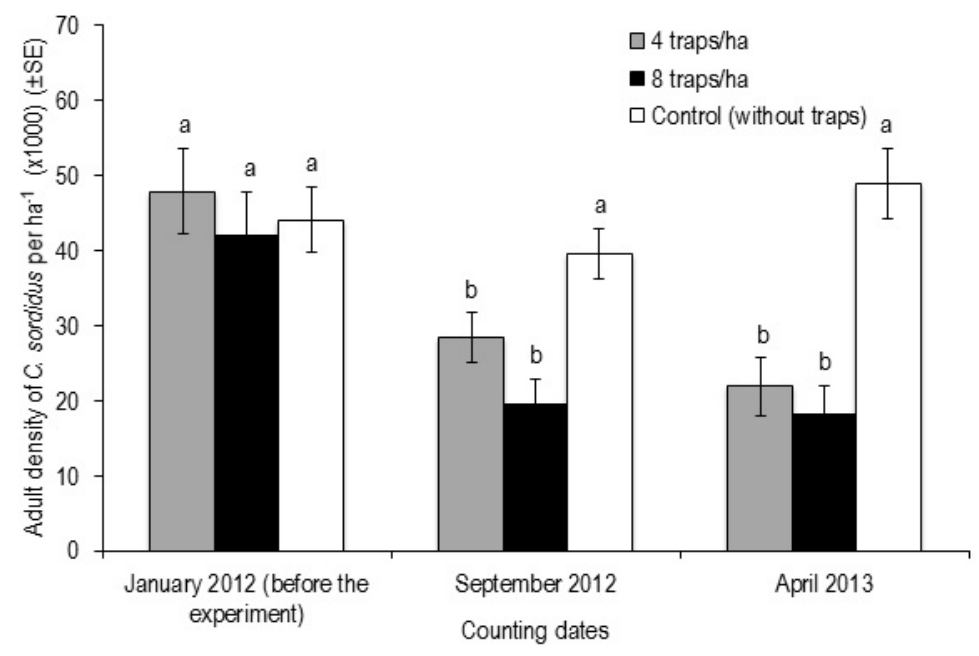

Figure 2. Adult Cosmopolites sordidus population behavior in Horn plantain Musa $A A B$ plots $(n=3$ plots per treatment), under mass trapping with traps baited with sordidin and plantain corm in Tabasco, Mexico. Bars with the same letter per counting date are not significantly different (Tukey, $\mathrm{p}>0.05$ ).

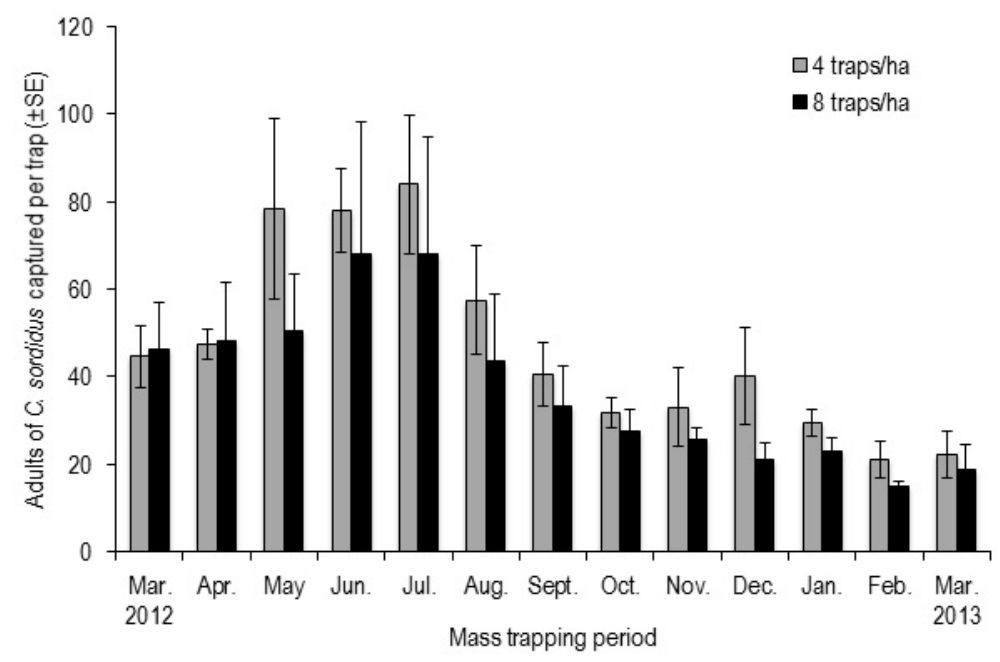

Figure 3. Number of adult Cosmopolites sordidus captured per trap per month in Horn plantain Musa AAB plots ( $n=3$ plots per treatment), under mass trapping based on traps baited with sordidin and plantain corm, in Tabasco, Mexico, from March 2012 to March 2013. Monthly capture rates were not significantly different (Student's t-test, $\mathrm{p}>0.05$ ).

Capture rates of both trap densities were not statistically different from each other throughout the trapping period $(p>0.05)$. Dissection of specimens found in the traps determined that a higher proportion of females than males were captured, between 0.68 and 0.79 according to the capture date, and the reproductive system of each female con- tained on average 2.4 to 2.7 eggs. The correlation between monthly capture rates and monthly rainfall in the study area was not significant $\left(R^{2}=0.49\right)$.

Prior to the start of trapping, the damage percentages in corms of mature (freshly harvested) plants were $15.5 \pm 2.7 \%$ in plots treated with four traps $\mathrm{ha}^{-1}, 14.5 \pm 1.3 \%$ in plots treated with 


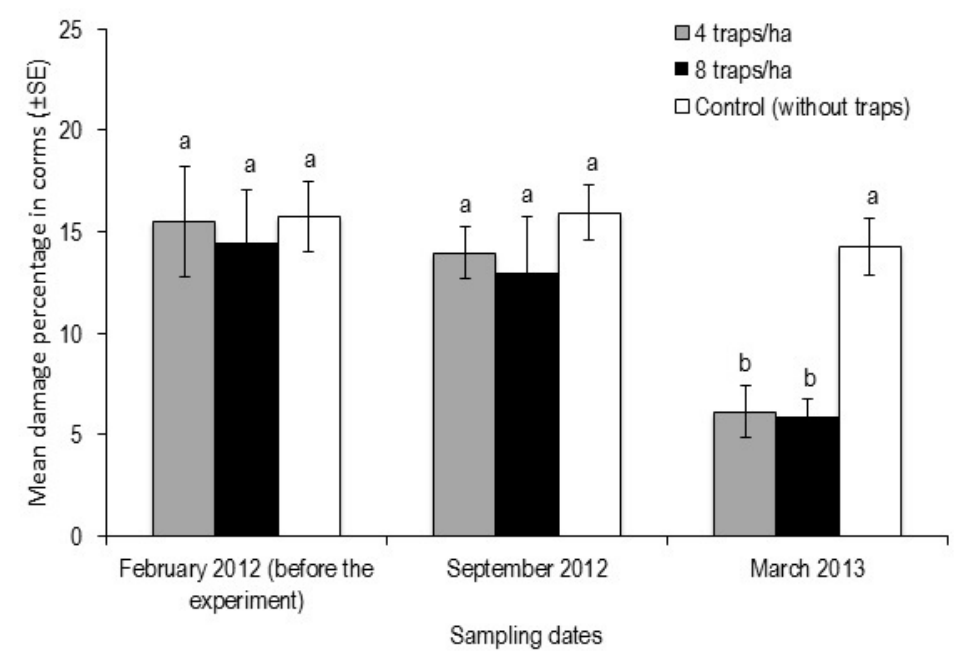

Figure 4. Damage percentages of Cosmopolites sordidus in corms of mature (freshly harvested) plants in Horn plantain Musa AAB plots ( $n=3$ plots per treatment), under mass trapping with traps baited with sordidin and plantain corm in Tabasco, Mexico. Bars with the same letter per sampling date are not significantly different (Tukey, $\mathrm{p}>0.05$ )

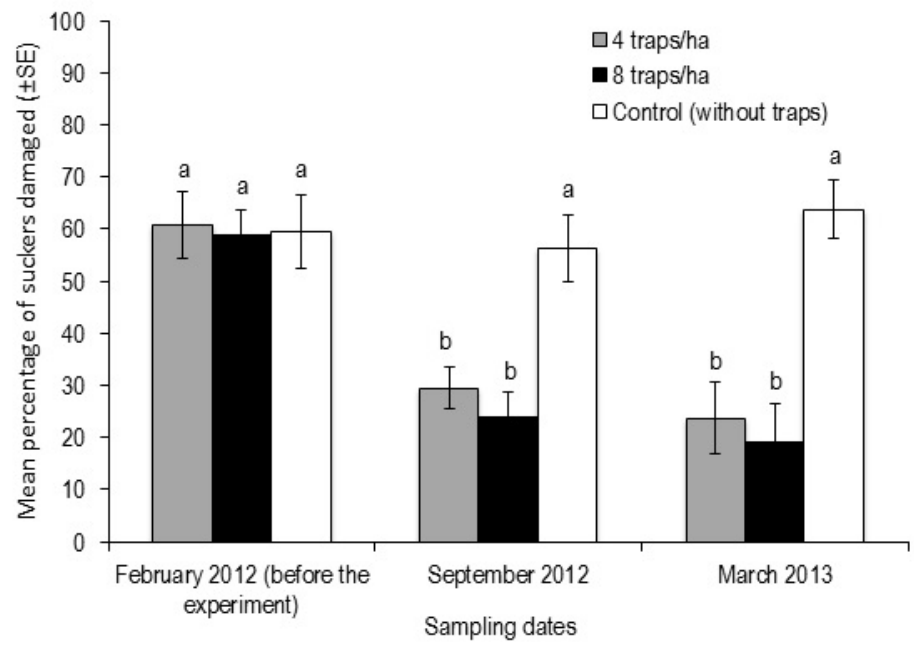

Figure 5. Percentage of suckers damaged by Cosmopolites sordidus in Horn plantain Musa AAB plots ( $\mathrm{n}=3$ plots per treatment), under mass trapping with traps baited with sordidin and plantain corm in Tabasco, Mexico. Bars with the same letter per sampling date are not significantly different (Tukey, $\mathrm{p}>0.05$ ).

eight traps ha ${ }^{-1}$ and $15.7 \pm 1.3 \%$ in untreated plots (control, without traps) (Figure 4). These percentages were not statistically different $(p=$ 0.09). Damage in both treatments was not reduced in the first six months of trapping, but decreased significantly by the end of 13 months of trapping ( $p$ $<0.05)$. In the plots with four traps ha ${ }^{-1}$ damage was reduced to $6.1 \pm 1.7 \%$, whereas in the treatment with eight traps ${ }^{-1}$ damage decreased to 5.9 $\pm 1.4 \%$. By contrast, in the control treatment the damage was statistically similar $(14.3 \pm 1.4 \%$ on average) to that found at the beginning of the experiment. The percentage of damaged suckers at the beginning of the experiment was $60.7 \pm 6.4 \%$ 
in plots with four traps ha ${ }^{-1}, 58.8 \pm 4.8 \%$ in plots with eight traps ha ${ }^{-1}$ and $59.6 \pm 7.0 \%$ in control plots (Figure 5). These damage rates were not statistically different $(p=0.81)$. After six months of trapping, the damage in both treatments was significantly reduced relative to the control ( $p<0.5)$. In the treatment with four traps ha ${ }^{-1}$, damage was reduced to $29.5 \pm 4.0 \%$, while in the treatment with eight tramps ha ${ }^{-1}$ damage decreased to 23.8 $\pm 4.7 \%$. After 13 months of trapping, damage percentages were not significantly lower compared to the intermediate evaluation $(p>0.05)$.

\section{DISCUSSION}

The capture rates of the weevil $C$. sordidus were from 20.9 to 84.0 weevils for four traps ha ${ }^{-1}$ and 14.8 to 68.1 weevils for eight traps ha ${ }^{-1}$, which were relatively high throughout the trapping period in relation to the economic thresholds established in Australia, where a capture average of 16 to 28 weevils per trap per month is indicative of economic damage (Murad 2001). Also, these capture rates were four times higher than that recorded by Tinzaara et al. (2005) in Uganda when assessing the same trap densities, where the same synthetic pheromone was used as bait. In the present study, the $C$. sordidus population density and the percentage of damaged suckers were reduced at six months after the start of the experiment, while the damage percentage in corms of mature plants was only significantly reduced at 13 months of trapping. These results partially coincide with those reported by Alpizar et al. (2012), who found a significant reduction in $C$. sordidus populations in banana plantations in Costa Rica, using traps baited with pheromone for 12 months. On the other hand, the results differ from those observed in Uganda, where the use of four or eight traps $\mathrm{ha}^{-1}$ baited with synthetic pheromone failed to reduce $C$. sordidus populations or damage at 21 months of trapping (Tinzaara et al. 2005). The low efficiency of this trapping system in Uganda was attributed to low-level crop management technology, in particular the association of plantain with other crops, poor weed control and the presence of crop residues that give sustenance and shelter to the pest in the plantation (Tinzaara et al. 2005). According to the results, it is very likely that the efficiency of the pheromone-based trapping system has increased with the addition of corm tissue in the traps, or otherwise, the impact of the trapping system is less efficient at low $C$. sordidus population densities, such as those in Uganda. In this research, the capture of specimens of both sexes, along with the higher proportion of females (range of 0.68 to 0.79 ) and their low number of eggs (2.4 to 2.7), supports the hypothesis that the reduced populations and damage observed was due to the mass trapping method. A reduction in females as well as males can significantly affect population figures (Howse et al. 1998). According to Alpizar et al. (2012) and Tinzaara et al. (2005), this method is based on the following assumptions: 1) the traps capture a high proportion of weevils within the bait attraction radius; 2) weevils are sedentary with limited immigration to those parts of the field covered by trapping; 3 ) the reproductive potential of the pest is low, leading to very slow population development.

The effect of rainfall on captures was not statistically significant. In general, the effect of climatic factors on $C$. sordidus captures has not been consistent. In the Martinique islands, for example, C. sordidus captures were associated positively with average temperature and negatively with precipitation (Duyck et al 2012), while in Uganda only relative humidity showed a significant positive relationship, as wind speed, temperature and rainfall had no effect (Tinzaara et al. 2005).

Regarding the effectiveness of the trap densities, there were no significant differences when comparing the monthly captures with four and eight traps $h^{-1}(p>0.05)$. Doubling the number of traps in this study did not significantly reduce the populations of $C$. sordidus, or the damage caused by the pest in the plantain crop. In general, when the number of traps was doubled, the number of weevils captured decreased from 12.5 to $47 \%$. This result can be attributed to possible interference between traps; i.e. when traps are placed 
near one another, their attraction radius can overlap (Liu et al. 2015). It is known that captures per trap unit may be lower when high rather than low trap densities are used (Schlyter 1992). Theoretically, the efficiency of mass trapping could be improved by increasing trap density, but high trap densities are neither economical nor practical (ElSayed et al. 2006). Under this premise, the use of four traps $\mathrm{ha}^{-1}$ baited with synthetic pheromone + fresh plantain corm tissue is considered effective to reduce heavy infestations of $C$. sordidus and severe damage caused by this pest on small farms under Horn plantain production conditions in Tabasco, Mexico. Added to this, some authors recommend implementing crop sanitation practices, such as timely disposal of crop residues (Masanza et al. 2004, Tinzaara et al. 2005, Masanza et al.
2009), while Gold et al. (2001) argue that the use of healthy material for planting, removal of crop residues and mass trapping with pheromones and kairomones can provide at least partial control of $C$. sordidus.

\section{CONCLUSIONS}

The use of four traps ha ${ }^{-1}$ baited with synthetic pheromone + plantain corm reduced $C$. sordidus populations and damage in Horn plantain Musa AAB plots in the Centro-Chontalpa region of Tabasco. This strategy can provide at least partial control of the pest under local Horn plantain production conditions without relying on the use of pesticides.

\section{LITERATURE CITED}

Alpizar D, Fallas M, Oehlschlager AC, Gonzalez LM (2012) Management of Cosmopolites sordidus and Metamasius hemipterus in banana by pheromone-based mass trapping. Journal of Chemical Ecology 38: $245-252$.

Beauhaire J, Ducrot PH, Malosse C, Rochat D, Ndiege IO, Otieno DO (1995) Identification and synthesis of sordidin, a male pheromone emitted by Cosmopolites sordidus. Tetrahedron Letters 36: 1043-1046.

Cerda H, López A, Sanoja O, Sánchez P, Jaffé K (1996) Atracción olfativa de Cosmopolites sordidus Germar (1824) (Coleoptera: Curculionidae) estimulado por volátiles originados en musáceas de distintas edades y variedades genómicas. Agronomía Tropical 46: 413-429.

Cerda H, Mori K, Nakayama T, Jaffé K (1998) A synergistic aggregation pheromone component in the banana weevil Cosmopolites sordidus Germar 1824 (Coleoptera: Curculionidae). Acta Científica Venezuela 49: 201-203.

Cibrián-Tovar J, Carrillo-Sa-nchez JL, Márquez-Santos M (2006) Evidencia de feromonas producidas por hembras del picudo del nopal, Metamasius spinolae (Gyllenhal) (Coleoptera: Curculionidae). Agrociencia 40: 765-772.

Duyck PF, Dortel E, Vinatier F, Gaujoux E, Carval D, Tixier P (2012) Effect of environment and fallow period on Cosmopolites sordidus population dynamics at the landscape scale. Bulletin of Entomological Research 102: 583-588.

El-Sayed AM, Suckling DM, Wearing CH, Byers JA (2006) Potential of mass trapping for long-term pest management and eradication of invasive species. Journal of Economic Entomology 99: 1550-1564.

Gold CS, Bagabe MI (1997) Banana weevil, Cosmopolites sordidus Germar (Coleoptera: Curculionidae) infestation of cooking and beer bananas in adjacent stands in Uganda. African Entomology 5: 103-108.

Gold CS, Peña JE, Karamura EB (2001) Biology and integrated pest management for the banana weevil Cosmopolites sordidus (Germar) (Coleoptera: Curculionidae). Integrated Pest Management Reviews 6: 79-155. 
Gold CS, Ragama PE, Coe R, Rukazambuga NDTM (2005) Selection of assessment methods for evaluating banana weevil, Cosmopolites sordidus (Coleoptera: Curculionidae) damage on highland cooking banana (Musa spp., genome group AAA-EA). Bulletin of Entomological Research 95: 115-123.

Howse PE, Stevens IDR, Jones OT (1998) Insect pheromones and their use in pest management. Chapman \& Hall, London. UK. 384p.

Jayaraman S, Ndiege IO, Oehlschlager AC, Gonzalez LM, Alpizar D, Fallas M, et al. (1997) Synthesis, analysis, and field activity of sordidin, a male-produced aggregation pheromone of the banana weevil, Cosmopolites sordidus. Journal of Chemical Ecology 23: 1145-1161.

Krebs CJ (1999) Ecological Methodology. 2nd ed. Adison-Welsey Logman, UK. 619p.

Larios-Romero J, Hernández J (1987) Condiciones ambientales para la agricultura en el estado de Tabasco. Revista de Geografía Agrícola 13-14: 33-42.

Liu H, Liu Z, Zheng H, Yang M, Liu J, Zhang J (2015) Effect of trap orientation and interval distance on captures of Isoceras sibirica Alpheraky (Lepidoptera: Cossidae). Journal of Agricultural Science 7: 161-166.

Masanza M, Gold CS, Van Huis A, Ragama PE (2004) Use of crop sanitation for the management of the banana weevil in Uganda. Uganda Journal of Agricultural Sciences 9: 636-644.

Masanza M, Gold CS, Van Huis A, Ragama PE (2009) Influence of plant and residue age on attraction, acceptance and larval survival of the banana weevil Cosmopolites sordidus (Coleoptera: Curculionidae). International Journal of Tropical Insect Science 29: 171-179.

Murad Z (2001) Using pheromones to trap banana weevil borers. Banana Topics, Issue 30/2001. DPI South Johnstone, Australia. 6p.

Minks AK, Kirsch PA (1998) Application of pheromones: toxicological aspects, effects on beneficials and state of registration. In: Haskell PT, McEwen P (eds.) Ecotoxicology, pesticides and beneficial organisms. Kluwer, London. pp: 337-347.

Muniappan R, Shepard BM, Carner GR, Aun-Chuan PO (2012) Arthropod pests of horticultural crops in tropical Asia. CAB International. Oxford, UK. 184p.

Muñiz-Merino M, Cibrián-Tovar J, Hidalgo-Moreno C, Bautista-Martínez N, Vaquera-Huerta H, AldamaAguilera C (2014) Compuestos volátiles atraen al picudo (Anthonomus eugenii Cano) del chile (Capsicum spp.) y presentan sinergia con su feromona de agregación. Agrociencia 48: 819-832.

Ndiege IO, Jayaraman S, Oehlschlager AC, Gonzalez LM, Alpizar D, Fallas M (1996) Convenient synthesis and field activity of a male-produced aggregation pheromone for Cosmopolites sordidus. Naturwissenschaften 83: $280-282$.

Osorio-Osorio R, Mollinedo-Hernández O y De la Cruz-Lázaro E (2006) Efectividad de trampas y atrayentes para la captura del picudo del plátano Cosmopolites sordidus (Germar). Entomología Mexicana 5: 720-724.

Paull RE, Duarte O (2011) Tropical Fruits, 2nd Edition, Volume 1. CAB International. Oxford, UK. 408p.

Piñero JC, Ruiz-Montiel C (2012) Ecología química y manejo de picudos (Coleoptera: Curculionidae) de importancia económica. En: Rojas JC, Malo EA (eds.) Temas selectos de ecología química de insectos. El Colegio de la Frontera Sur, México. pp: 361-400. 
Ramírez SG, Rodríguez CJC (2003) Tecnología para la producción de plátano en Tabasco. Fundación Produce Tabasco A.C., Villahermosa, Tabasco, México. 65p.

Reddy GVP, Cruz ZT, Guerrero A (2009) Development of an efficient pheromone-based trapping method for the banana root borer Cosmopolites sordidus. Journal of Chemical Ecology 35: 111-117

Rukazambuga NDTM, Gold CS, Gowent SR (1998) Field loss in East African highland banana (Musa spp., AAA-EA group) caused by the banana weevil, Cosmopolites sordidus Germar. Crop Protection 17: 581-589.

SAS Institute Inc. (2009) SAS/STAT 9.2 User's Guide. Second Edition Cary, NC, USA. 7869p.

Schlyter F (1992) Sampling range, attraction range and effective attraction radius: estimates of trap efficiency and communication distance in coleopteran pheromone and host attractant systems. Journal of Applied Entomology 114: 439-454.

Tinzaara W, Dicke M, Van Huis A, Gold CS (2002) Use of infochemicals in pest management with special reference to the banana weevil, Cosmopolites sordidus (Germar) (Coleoptera: Curculionidae). International Journal of Tropical Insect Science 22: 241-261.

Tinzaara W, Gold CS, Kagezi GH, Dicke M, Van Huis A, Nankinga CM, et al. (2005) Effects of two pheromone trap densities against banana weevil Cosmopolites sordidus populations and their impact on plant damage in Uganda. Journal of Applied Entomology 129: 265-271.

Tinzaara W, Gold CS, Dicke M, Van Huis A, Ragama PE (2007) Host plant odours enhance the responses of adult banana weevil to the synthetic aggregation pheromone (Cosmolure+ ${ }^{\circledR}$ ). International Journal of Pest Management 53: 127-137.

Wyatt TD (2003) Pheromones and animal behaviour communication by smell and taste. Cambridge University Press, UK. 391p.

Zar JH (2010) Biostatistical analysis. Fifth Edition. Prentice Hall, Inc. New Jersey. 944p. 
